\title{
The dynamic relationship between sense of place and risk perception in landscapes of mobility
}

\author{
Tara Quinn $^{1}$, Francois Bousquet $^{2}$, Chloe Guerbois ${ }^{3}$, Elias Sougrati ${ }^{2}$ and Matthieu Tabutaud ${ }^{2}$
}

\begin{abstract}
Coastal areas are exposed to changing patterns of mobility and increasingly extreme weather events, offering unique opportunities to study the complexity of adaptation to global changes and the diversity of responses to risk. How individuals and communities respond to risk varies widely, however traditional rationalist and economic based understandings have proved limited in explaining responses to risk. Increasingly social science, and specifically, a focus on peoples' relationships with their local places is providing a useful approach to understanding human responses to place based change. We bring together literature on sense of place, mobility, risk perception, and adaptation and develop a conceptual model to highlight the dynamic links between these processes. In particular we concentrate on a way of understanding risk that focuses on the role of different types of attachments to place. We explore this model using a pilot study $(n=70)$ and present data that indicates how different types of place attachments are significant in whether people perceive themselves to be at risk of flooding. Our review and results emphasize the interconnectivity of social and environmental change, and suggests that by identifying particular place attachments, as shaped by mobility, we can deepen our understanding of how communities choose to respond to risk.
\end{abstract}

Key Words: adaptation; place attachment; risk; mobility

\section{INTRODUCTION}

Over $40 \%$ of the global population is living in coastal areas and more than half of the world's countries have $80-100 \%$ of their populations living within $100 \mathrm{~km}$ of the coast (Martínez et al. 2007). These populations have to manage a range of risks; the physical changes brought to bear by climate change coupled with the shifting patterns of mobility are reshaping vulnerability to a number of processes (McGranahan et al. 2007, De Sherbinin et al. 2012, Watts et al. 2015, Surjan et al. 2016). How people adapt to these risks is a topic of policy and research interest. We know that rationalist and economic analyses of risk that focus on information dissemination and costs and benefits do not adequately take into account the emotional drivers involved in the construction of risk (Finucane et al. 2000, Wachinger et al. 2013). The importance of social processes in shaping decision making around environmental change has been identified (Grothman and Patt 2005, Adger et at. 2009), and key to understanding adaptation to environmental change is clarifying how and when people and communities begin to perceive change as a risk to themselves. To this end, the sense of place literature offers a potentially particularly useful lens for understanding how situated risk is perceived and acted on individually and collectively (Wester-Herber 2004, Billig 2006, Bernardo 2013, De Dominicis et al. 2015, Rey-Valette et al. 2015).

Environmental psychologists and sociologists have developed several concepts - sense of place, place meaning, place attachment - to study people's relationship with place, and have demonstrated its role in place-related attitudes and behaviors (Burley et al. 2007, Lewicka 2011a, Willox et al. 2012), however there is an underrepresentation of sense of place in adaptation planning and decisions (Agyeman et al. 2009, Adger et al. 2011). Social-ecological systems (SES) literature has started to engage with place theory to better understand how people register, experience, and manage SES change (Chapin and Knapp 2015,
Stedman 2016, Masterson et al. 2017). In particular, a socialecological approach encourages a dynamic understanding of sense of place, emphasizing that the way people relate to their local areas sits within, and is connected to, wider social and ecological changes.

A dynamic approach to sense of place is appropriate for studying responses to social and environmental change in coastal regions, areas that globally are experiencing significant demographic changes largely due to migration, as people move for economic and climatic reasons (Neumann et al. 2015). Processes of urbanization are particularly prevalent in coastal areas (Surjan et al. 2016), where tourists are attracted during high seasons, with wealthy groups investing in second-homes and developing distinct relationships with place (Rey-Valette et al. 2015). As a result some coastal regions are experiencing significant shifts in local rural and maritime identities. In his review of mobility and place literature Gustafson (2014) suggests that understanding such mobility patterns is essential to understanding variations in sense of place within populations, with differences evident between long-time residents and mobile in-migrants. However, very little empirical material considers how a diversity of relationships with place, shaped by mobility processes, influences risk perception and subsequent adaptation decisions.

We focus on the dynamic construction of sense of place in communities and examine how it sits within, and interacts with, wider social and environmental processes. We first present a brief overview of sense of place concepts, and strategically review literature on risk perception, mobility, and adaptation to suggest a new area of enquiry. From this synthesis of previous studies we develop a conceptual model highlighting the iterative links between these different processes and explore these links empirically with a pilot study on perception of flood risk in two towns in southern France. From our review and findings we

${ }^{1}$ University of Exeter, ${ }^{2}$ CIRAD, UPR GREEN, Montpellier, France, ${ }^{3}$ Nelson Mandela University, Sustainability Research Unit, George, South Africa 
emphasize the dynamic relationship between place, risk, adaptation, and mobility and we suggest how this approach to sense of place can help to develop an understanding of collective and individual experiences and choices relating to social and environmental change.

\section{WHAT IS SENSE OF PLACE AND HOW DO WE MEASURE IT?}

Sense of place is an overarching term for a number of different approaches and terms describing people's relationship with their environment (Lewicka, 2011a, Stedman 2016). One of these terms (sometimes used interchangeably with sense of place) is place attachment, which evolved from Bowlby's (1969) theory of attachment between children and their caregivers; this theory centers on an infant's desire to maintain closeness to the object of attachment and the impact of this relationship on well-being (Bowlby 1969, Hidalgo and Hernandez 2001, Morgan 2010). It has since been operationalized in a number of fields of research including environmental psychology, leisure studies, environmental education, and migration studies.

There are a number of conceptual approaches to understanding and studying sense of place, reflecting different epistemological understandings of human/environment relationships. In the last 40 years, positivist approaches used to measure sense of place and its relation to attitudes and behavior in environmental psychology has generated a large body of data; often such studies focus on measuring the strength of attachment to a place, and/or the symbolic meaning that people assign to places. Strength of attachment to place is usually measured using psychometric scales (on a scale of 1-5) and studies often include three different dimensions of human relationship with place: place dependence, place attachment, and place identity (Lewicka 2011a).

Place meaning is qualitatively different to measures of attachment (Brehm et al. 2013). Attachments are about strength of feeling for a place, and meanings reflect the symbolic significance of a place to a person. Place meaning evolves through individual and group experiences and memories (Stedman 2003). It can be investigated using qualitative research methods, whether through interviews or open-ended survey questions (Jacobs and Buijs 2011). When place meaning is operationalized in mixed methods positivist research it has been measured through asking respondents their level agreement with descriptive statements about their locale, e.g., my lake is a place to escape from civilization (Brehm et al. 2013, Jacquet and Stedman 2013), or through the word association tasks (Devine-Wright and Howes 2010, Clarke et al. 2018).

As Lewicka states in her review of the evolution of place research "The various place attachment measures thus should be treated as an 'extended family' of methods rather than as precise measurement tools with well tested construct validity" (Lewicka 2011a:220). These methods continue to evolve, and increasingly a mixed methods approach combining meanings and attachments are mobilized to examine sense of place, an approach that we take for our study.

\section{Varieties of place attachment}

Conventional place attachment scales have highlighted interesting dynamics linking place and other variables, but can be limited in their ability to deal with variations in types of attachment within the populations studied. There is a need for more nuanced place scales to allow for finer grained analysis of how people relate differently to their local area. To this end, Lewicka (2011b) adapted Hummon's (1992) qualitative typology of people's relationship with place into a quantitative tool for measuring different types of attachment to place. This resulted in the identification of five types of place attachment: inherited, active, alienation, relativity, and placelessness.

The five categories reflect not only the strength of relationship with place, but to a certain extent the meaning that these emotional attachments rest on. For example, both inherited and active place attachment styles reflect positive relationships with place, however, for quite different reasons. Inherited attachment represents a relationship with place that is related to long-term connections, close family ties, and to a certain extent an unquestioned identification with place. Active attachment is formed when people consciously chose to live somewhere because it reflects a part of their identity and an important part of an individual's lifestyle. The three other types of place attachment (that are closely related), place alienation, relativity, and placelessness reflect different types of nonattachment to place. People who are place alienated actively dislike a place, and would choose to leave if they could. Place relative individuals hold an ambivalent relationship with place; they are able to form bonds with places but would be equally be content to change between a numbers of places. Nonattachment in the form of placelessness describes individuals who do not identify with their place of residence. This scale has been operationalized by Lewicka (2013) since her $2011 b$ paper and by Devine-Wright (2013), both finding meaningful differences between the different place attachment types.

In refining measures of place, researchers are better able to explore and potentially explain how different dimensions of sense of place influence perceptions, attitudes, and behavior. We suggest that place attachments and place meanings are key in understanding individual and community response to place-based risks, and we use Lewicka's refined place scales to empirically explore our hypotheses. We strategically review literature to identify processes linking place, mobility, adaptation, and risk and we explore the links that form our conceptual model outlined (Fig. 1) below. Our intention is not to identify a closed model, but instead is to suggest how sense of place interacts with other processes and to propose what this may mean for how communities experience and manage social and environmental change.

Fig. 1. Conceptual model of the relationships between mobility, place attachment, risk perception, and adaptation.

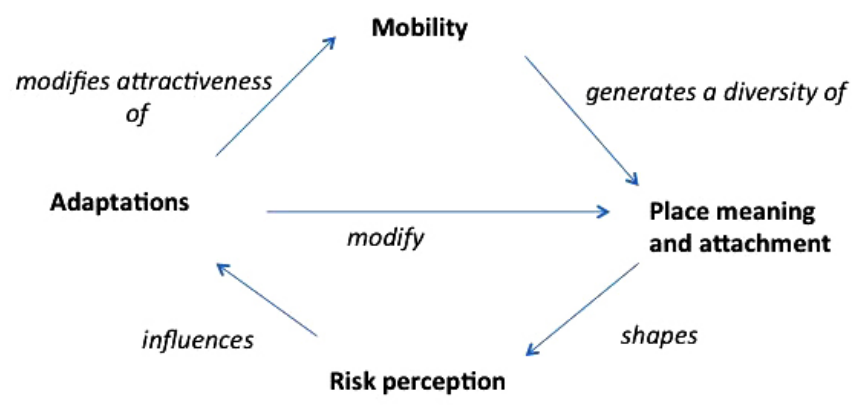




\section{THE DYNAMIC INTERACTIONS BETWEEN SENSE OF PLACE, RISK, ADAPTATION, AND MOBILITY}

How does place attachment shape experience of risk?

Jaeger et al.'s definition of risk highlights the centrality of human attachments in risk construction: a risk is "a situation or event in which something of human value (including humans themselves) has been put at stake and where the outcome is uncertain" (2013:17). The mechanisms put forward in the literature explaining how place attachment shapes perceptions of risk are often a variation on a theme of an individual or group striving for a sense of continuity or coherence (Fullilove 1996, Fried 2000). If you value a place, a threat to that place is stressful, and can sometimes be cognitively managed by reducing the salience of the perceived threat (Bernardo 2013). The risk literature has demonstrated how emotions can mediate perceptions of risk, with positive emotions about an object connected to reduced perceptions of risk and increased perceived benefits. The more positive emotion a person attaches to an object or an event, the smaller the level of perceived risk from that object (Finucane et al. 2000). What is meaningful about a place, either a residence or a hometown, shapes how people perceive and experience risks (link between place and risk perception in Fig. 1).

From a place identity perspective, the more a person identifies with a place the more likely one is to align positive attributes with that place in order to reinforce a positive self-image (Bonaiuto et al. 1996). Korpela (1989) highlights the role of place identity in the regulation of a person's environment: places act as references for past significant events and so place continuity is part of a wider process of identity management. Easthope (2009) draws on Bourdieu's concept of habitus to explain the relationship between self and place. It is in places where our habitus developed that we are likely to feel at home and connected and are thus more likely to want to manage such places in a way that promotes stability.

Place attachments and place meanings can therefore determine how people assign risk to local places, and subsequently, place related risk perceptions can ultimately influence the adaptations that people make and support (link between risk perception and adaptation in Fig. 1). Tim Harries (2008) uses social representation theory to explain why not making changes to one's house in the face of risk can be considered a rational decision. He focuses on Gidden's idea of ontological security: "an ontologically secure person is someone who is free from existential doubts and who is able to believe that life will continue in much the same way as it always has" (Harries 2008:482). Applying the idea of ontological security to home, home presents a representational barrier through which information must pass and the power and resonance of incongruent information that challenges the security of home is therefore reduced. For this reason people may chose not to install flood doors or change sockets because these are visible signs of threat that would undermine everyday feelings of security. This alternative rationality for adaptation behaviour, inaction as a way of maintaining well-being, was also reflected in research carried out by De Dominicis et al. (2015) into flood risk in two Italian cities and found that for households at risk, if place attachment is strong then the relationship between risk perception and action is weaker.
The significance of relationship with place in adaptation decisions aligns with Grothman and Patt's (2005) conceptualization of the socio-psychological drivers of adaptation that puts risk perception as central to the adaptation decision-making process; indeed risk perceptions in part determine the social limits of adaptation (Adger et al. 2009). Risk perceptions, as well as shaping direct adaptation action, also shape policy preferences for larger scale adaptation to change (Leiserowitz 2006). By examining people's relationships with their local places through such socio-psychological processes it becomes clearer how feelings of continuity and control over place change contributes to well-being. More specifically, interpreting choices for adaptation through a sense of place lens helps to clarify why people hold attitudes or behave in a manner to maintain the integrity of their relationship with the places that matter to them, perhaps even when this seems at odds with objective levels of risk.

How mobility shapes configurations of place attachment within communities and the implications for social differentiation of risk Lewicka (2011a) highlights that there is much evidence that long residence time and strong community links predict strong place attachment: the longer someone lives in place the more attached they are likely to be (Brown et al. 2003, Anton and Lawrence 2014). But what does this mean for other people? What does this mean for people who move often, who do not have familial or strong social links to place? In an increasingly mobile world how do different social groups vary in their type of place attachment? More specifically, for our work, we are interested in what these dynamics may ultimately mean for how different groups perceive place change and risk.

Different social groups have different types of relationships with local places as cultural and socio-psychological processes result in particular place meanings for different people (Masuda and Garvin 2006, Stedman 2006, Hernández et al. 2007). Our focus on how mobility processes in coastal areas may contribute to changing compositions of sense of place builds on evidence that the more mobile elements of a population express different place meanings compared to those that are more physically rooted (Masterson et al. 2017). When people move to an area, they can establish emotional attachments of similar strength to those of longer term residents, but their place identity can be different, because place identity takes a longer time to develop than emotional bonds (Knez 2005, Hernández et al. 2007). Second home owners assign different meanings to their homes to that of locals because second home owners' place meanings are more likely to be focused on environmental quality and place as an escape (Stedman 2006). Indeed, new arrivals can reshape how longer term residents feel about their local areas, triggering in some the development of nostalgia where long-term residents feel differently to their new community members, and so no longer feel at home in their place (Savage 2010). Increased mobility and cosmopolitanism has changed the nature of the way some populations relate to place, however the pull of home remains important (Gustafson 2001). Ultimately, mobility patterns can generate a diversity of place attachments and place meanings (link in Fig. 1 between mobility and place meanings and attachments).

The processes linking mobility, place, and risk do not just occur at the individual psychological level; cultural processes and 
worldviews interact collectively to rationalize certain risks over others (Jaeger et al. 2013). Masuda and Garvin (2006) examine why people with different cultures amplify or attenuate risk associated with a particular eco-industrial development proposal. They show that risk communication is socially (strategically) amplified or moderated by different groups of people (residents and nonresidents) with the objective of defending a point of view on place. Billig (2006) shows that mobility, political relationships, and ideologies underpin certain place attachments. In the specific case of Israeli colonies in Palestinian territories, Billig finds that Israeli residents hold a diversity of place meanings, which are associated with variations in risk perception. Long-term residents have higher levels of attachment relative to new comers and where place attachment is related to ideological roots, there is a lower perception of threat from attacks. Ultimately, changes within populations associated with mobility are linked to changes in the configurations of sense of place within communities and this process can ultimately cause changes in how place based risks are perceived.

\section{Adaptation and changing places}

Adaptation can occur across scales, and residence scale adaptation as well as settlement scale infrastructure can affect both sense of place and decisions around mobility. The link between environmental change and mobility is multifactorial and complex (Tacoli 2009, Adamo 2010, Adams 2016) and a review of the mobility literature is beyond the scope of this article. We focus specifically on the relationship between mobility decisions and adaptation. In response to environmental change, selfperceived adaptive capacity and large-scale adaptation intervention can modify the attractiveness of mobility choices (link in Fig. 1 between adaptation and mobility). Should you move? And if so, where to? De Sherbinin et al. 2011, considering the impact of previous large-scale infrastructure projects, identify the potential of future large-scale adaptation schemes to influence population movement, e.g., through the construction of sea walls or water reallocation projects. Adaptation, both at the individual and collective scale, has implications for whether communities and people stay in place. At a collective scale, the political choice to climate proof or risk proof settlements allows or even encourages people to inhabit flood risk zones (McCaughey et al. 2018). However, lack of adaptation options or investments means that individuals and groups may be ambivalent about living somewhere if they do not experience ontological security (Hawkins and Maurer 2011) or may have to choose relocation when changes in landscape means staying in place is untenable (McLeman 2011, Maldonado et al. 2013)

Large-scale physical changes to places, either man-made (Cheng and Chou 2015, Von Wirth et al. 2016) or environmentally driven (Adger et al. 2011, Ellis and Albrecht 2017), modify attachment to, and meaning of, places (link in conceptual model between adaptation and place attachment and place meanings). Although the impact of adaptation projects are largely yet to be felt, we agree with Devine-Wright (2014) and hypothesize that future large scale adaptation projects are likely to reshape place meanings and place attachments. These impacts are will be most keenly felt by those with strong bonds to existing places (Cheng and Chou 2015, Clarke et al. 2018).
In summary, our review of the literature suggests dynamic and interlinked relationships between sense of place and wider processes of risk, adaptation, and mobility (see Fig. 1). Shifts in one part of the model can reinforce or change other processes in the model. As highlighted above, this is not a closed system, but is one that focuses on the iterative nature of sense of place and its role in social and environmental change. Figure 1 illustrates the links and structure of the processes our review of the literature suggests and we explore this model empirically with a pilot study.

\section{PILOT STUDY ON FLOOD RISK ADAPTATION: TWO SETTLEMENTS WITH DIFFERENT MOBILITY PATTERNS AND ADAPTATION PATHWAYS}

Within a research project on management of coastal change (MAGIC), we have selected two towns in Southern France for a pilot study to explore and discuss the relevance of the conceptual model presented in Figure 1. After a brief description of the context in the two towns we structure this section according to the different interactions outlined in the conceptual model.

Both the towns in our study are experiencing demographic shift driven by migration and, at the same time, changes in exposure to flood risk. The first town, Lattes, 15,963 inhabitants in 2015 (INSEE 2015), is situated on the river Lez and borders the city of Montpellier (approximately 300,000 inhabitants). The second town, Sommières, 4644 inhabitants in 2015 (INSEE 2015), is situated on the river Vidourle, approximately $30 \mathrm{~km}$ from Montpellier (Fig. 2). These two settlements are prone to riverine flash floods that are typical of the coastal Mediterranean region and its associated climate and hydrology: short watersheds (less than $100 \mathrm{~km}$ ) exposed to significant flash flood events during autumn when the differences in temperature between the sea (warm) and the air coming from north (cold) generate heavy rains. These storms can cause tidal surges that constrain the flow of water to the sea, increasing the risk and intensity of river floods. There is no statistical evidence of a climatic shift in the frequency of storm episodes, however the mobility patterns in the last 20 years has driven increased urban development in this region (ADEME and Meteo-France 2011) with both towns experiencing demographic growth in the last 20 years reflecting wider urbanization trends (Surjan et al. 2016). Urban areas have expanded, often located in areas exposed to flood risk, and the associated land-cover transformations have increased and amplified rates of surface water run-off. As a result, migration patterns have created new configurations of exposure and vulnerability to flood risk.

\section{Methods}

To investigate the links in the conceptual model outlined in Figure 1 , we collated information from scientific literature, historical policies, archives, and conducted 15 semistructured interviews with elected people, members of local associations, and local historians. We also designed a semiquantitative questionnaire survey ( $n=35$ in each town) to explore the links between mobility, place attachment, adaptations, and flood risk perception. The surveys were carried out in July and August of 2015 in several public spaces in the two towns as well as at residents' houses and at different times of day to ensure a diversity of informants (in terms of exposure). The survey included five sections; these sections focused on place meaning and attachment; risk 
Fig. 2. Map showing location of study sites Sommieres and Lattes in southern France.

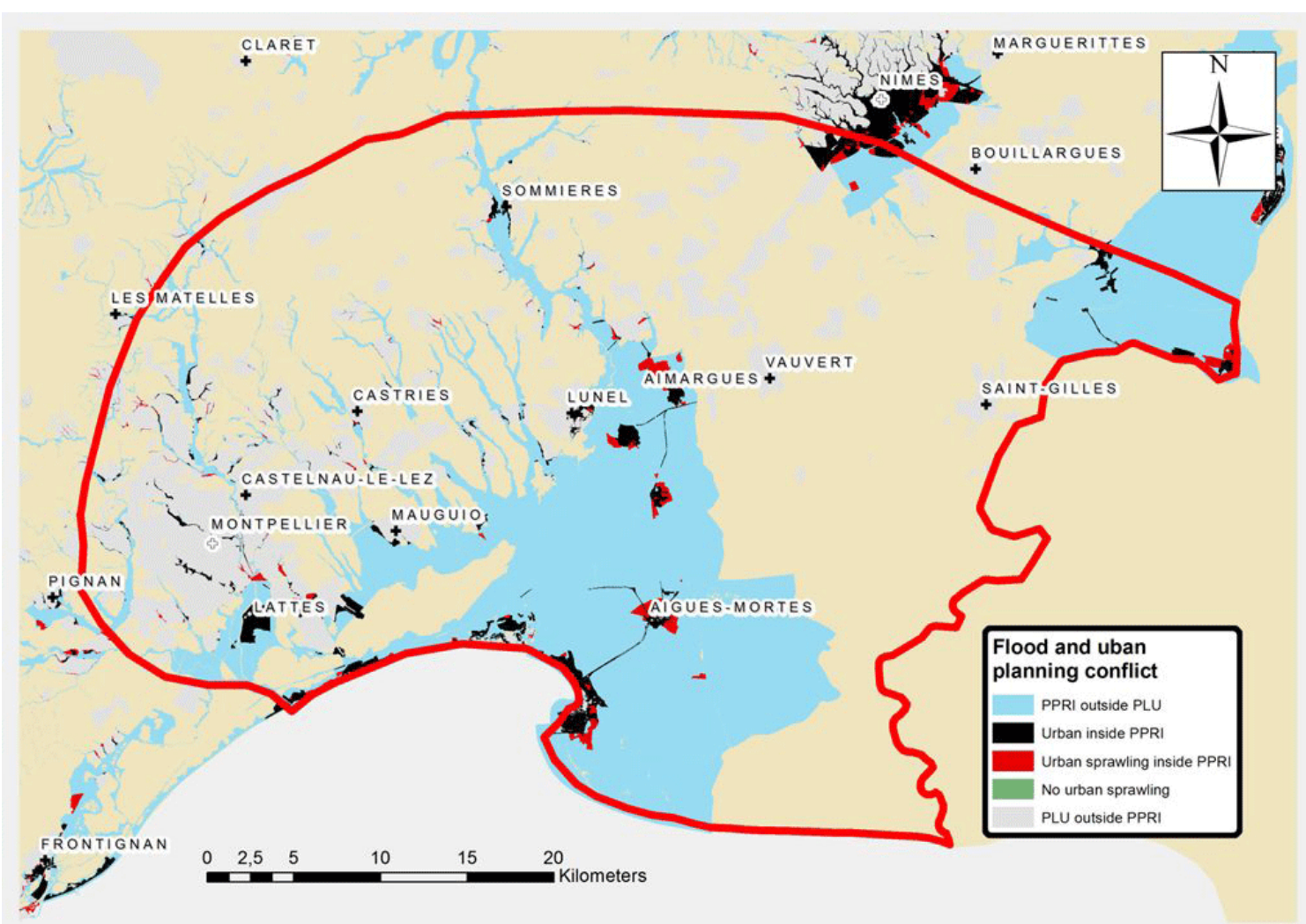

perception; sense of water; adaptive capacity; and informant characteristics, including reasons for settling in the area and time of residence used as proxies of mobility. To investigate place meaning, we asked people to give three words to describe their town that were then coded into categories: quality of life, heritage, water, rural status, location, economic status, and youth by the authors. In line with current quantitative place attachment work we used multi-item scales to measure individual place attachment (Lewicka 2005, Devine Wright and Howes 2010). Our results reflect how the respondents feel about their town at that particular moment in time. As Bailey et al. (2016) demonstrate, such place attachments can change through the life course.

We used two scales, one that we label a conventional place scale, permutations of which have been used in a number of studies (for example Lewicka 2005). Second, we included a scale that includes items on the different place attachment types as set out by Lewicka's adaptation of Hummon's work (Lewicka 2011b). Because of the design of the study and low sample size, we included items for three types of place attachment out of the five described by Lewicka (2011b): both of the positive types of place attachment (inherited and active) and items that reflect a relative place attachment. For risk perception, informants were asked to identify three main risks at three spatial scales (residence, neighborhood, town) and to rank them on a scale of 1 to 5. The main reasons for settling in the two towns, a proxy of mobility, were coded into five categories: Born here, Environment, Family, Facilities, and Retired. Exposure was coded in two categories (Yes and No) according to whether people lived on designated flood plains (maps provided in Appendix 1 and 2; No was coded for flooding probability $=0$, which are the parts of space over the limits of exceptional floods, yes for any positive probability to be flooded). Perceived flood risk at city and neighborhood scale were measured using a Likert scale and transformed into a multinomial ordinal response variable $(-2=$ Strongly disagree, $-1=$ Disagree, $0=$ Neither agree nor disagree, $1=$ Agree, $2=$ Strongly Agree $)$. We conducted a multiple correspondence analysis to explore the link between place attachment (Conventional, Inherited, Active, and Relative), mobility (Reason for settling in the area), exposure, and perceived risk at the scale of the city and the neighborhood.

The multinomial ordinal response variables (CityRisk and NeighbourhoodRisk) were analyzed using odds proportional logistic regressions. Statistical analyses were performed with the $\mathrm{R}$ software version 3.2.5. In particular, we used the function dudi. hill smith of the package ade4 to perform multivariate analysis with mixed quantitative variables and factors (Dray and Dufour 2007) and the polr function of the package MASS for proportional-odds logistic regressions (Venables and Ripley 2002).

\section{RESULTS}

\section{Risk perceptions influence adaptations}

Data gathered from archives and interviews suggest that half a century ago these two towns were similar in the way they managed living with autumnal river floods (town scale flood risk maps are 
provided in the Appendices). Lattes (Appendix 1) was a village of farmers whose houses were located in elevated locations and for whom the autumn floods were manageable events. Sommières (Appendix 2), a town built partly on the riverbed, has a long history of flooding and adaptive strategies to deal with these autumnal floods (monitoring the upper watershed, warning systems, rapid transfer of belongings to the upper floors). In autumn 2002, the same meteorological event resulted in significant flooding in the two towns, but the responses differed. Whereas policy makers and residents in Sommières continued to align with a "living with the risk" approach, decision makers in Lattes reoriented their management approach toward that of "protection from risk" and started investing in costly hard infrastructures (dykes, canals) to protect the population from flood risk. As demonstrated by political discourses, management documents, and interviews, floods were no longer acceptable in Lattes. Lattes is part of the urban area of Montpellier and urban planning, designed in the 1960s, has targeted this area for the expansion and settlement of big infrastructure. On the other hand, Sommières, far from the cities, is not a targeted development area and has evolved an identity of a town that "lives with floods." These different perceptions of the acceptability of risk has led to different adaptation pathways in the two towns.

\section{Adaptations modifies attractiveness of place}

In Lattes, after the construction of the dykes the price of land increased and agricultural land was transformed into urban areas, attracting wealthy people working in Montpellier who wanted attractive housing close to their workplace. Lattes' reliance on Montpellier's economic activity has fostered the development of new infrastructures for transport (highway, high speed train) at the expense of agricultural areas. The newcomers settle in the socalled protected area, behind the dykes. Consequently, the population in Lattes is broadly separated into two social and spatial groups: the group of people who settled a long time ago in the elevated locations and the group who settled more recently (after 1980) in the new neighborhoods protected by the infrastructures. This evolution in the character of Lattes' population was described by many interviewees, as reflected in following quote:

\begin{abstract}
The structure of the population is not the same as when the process of urbanisation started. Older people left and the population is becoming younger. (...) At PortArianne (a new neighbourhood) house prices are high. There is a high standard of housing, with swimming pools etc. It's calm and close to everything. The 'clients' are mostly from the higher economic classes, often coming from another region. They come and go. Mr. A., Lattes, elected member of Town Council.
\end{abstract}

Further from Montpellier, Sommières attracts people prepared to spend more time commuting, and who cannot afford to live close to the big cities. The historical center of Sommières is renowned for its medieval architecture and attracts high numbers of tourists. However, it regularly experiences significant floods and as a result rental prices near the center, which is on the riverbed, are relatively inexpensive. In Sommières, we identified three social and spatial groups: a neighborhood in the old center where vulnerability to floods is well known and where a mix of old families and poor newcomers live; a neighborhood on the flood plain that is exposed to exceptional floods; and a neighborhood in the elevated areas where the richer newcomers have settled. Although socioeconomics shapes movement within these towns, what is clear in Lattes is that infrastructure for adaptation has allowed the development of a distinctive place meaning that has altered the demographics of who is attracted to the town.

\section{Mobility generates a diversity of place attachments and place meanings}

In Sommières the three most cited categories of place meanings were the following: quality of life (beautiful, peaceful, pleasant), heritage (historical, birth place), and water and rural status. River and Floods were mentioned first in the word association question in 6 of the 35 surveys. For people in Lattes, quality of life was the most common meaning followed by youth (young town, novel), wealth, and proximity to Montpellier but River and Floods were not mentioned. These place meanings results depict the difference between Sommières' residents who hold meanings that are tied to history and the river and its floods, and Lattes' residents who perceive their town as young, close to the city and its activities but do not mention the presence of the river and its floods. Facilities were the main reason for respondents choosing to live in Lattes (60\% of informants) while only $20 \%$ stated that they settled for that reason in Sommières, the main reason there being family connections.

If we consider conventional place attachment (PA), our results show that conventional PA was positive in the two towns and slighter higher in Sommières $(0.53 \pm 0.14)$ than for Lattes $(0.25$ $\pm 0.10, p=0.05)$. If we look at the three place attachment types (inherited, active, and relative) we find a greater diversity of place attachment types in Sommières than in Lattes (illustrated by the size of the ellipses Fig. 3.A)

The results for place attachment align with the results for place meaning, and highlights that the populations in both settlements relate quite differently to their respective towns. These place meanings and place attachment patterns are consistent with the two towns' histories. As discussed above, Lattes is mostly composed of people who settled recently with the intention of finding an amenable place, close to Montpellier city and close to nature. In Sommières there is a high diversity of population, some who have been living there for generations attached to the heritage of their city and the relationship with the river, and some who settled more recently for the services Sommières can provide.

We also looked at the relationship between PA types and the reasons for settling in towns (illustrated in Fig, 3A, B). Respondents who lived in the town in which they were born (Est $=0.98 \pm 0.19 \mathrm{SE})$ and settled for the environment $(0.92 \pm 0.29)$ show significantly greater attachment than those settling for facilities $(0.37 \pm 0.21)$, family $(0.04 \pm 0.23)$, and retirement $(0.20$ $\pm 0.29)$. Place attachment also significantly increased with time of residence $(\mathrm{t}=2.326, \mathrm{p}=0.023)$. People who were born here, or settled for environment, family, or retirement $($ Est $=0.57 \pm 0.25)$ had a significantly higher score of Active PA in contrast with those settling for facilities $(-0.9 \pm 0.28)$ who were significantly negatively related to Active PA $(F 4,66=4.60, p=0.002)$. We found no significant effect of time of residence on Active or Relative PA. 
Fig. 3. Results of the multiple correspondence analysis combining place attachment (PA) modalities, conventional place attachment (A), reasons for settling (B), exposure and risk perception at the neighborhood and the city scales $(\mathrm{C})$. Ellipses represent dispersion of the response at the town scale. The cumulative effect of the first two axes accounts for $41 \%$ of the variability.

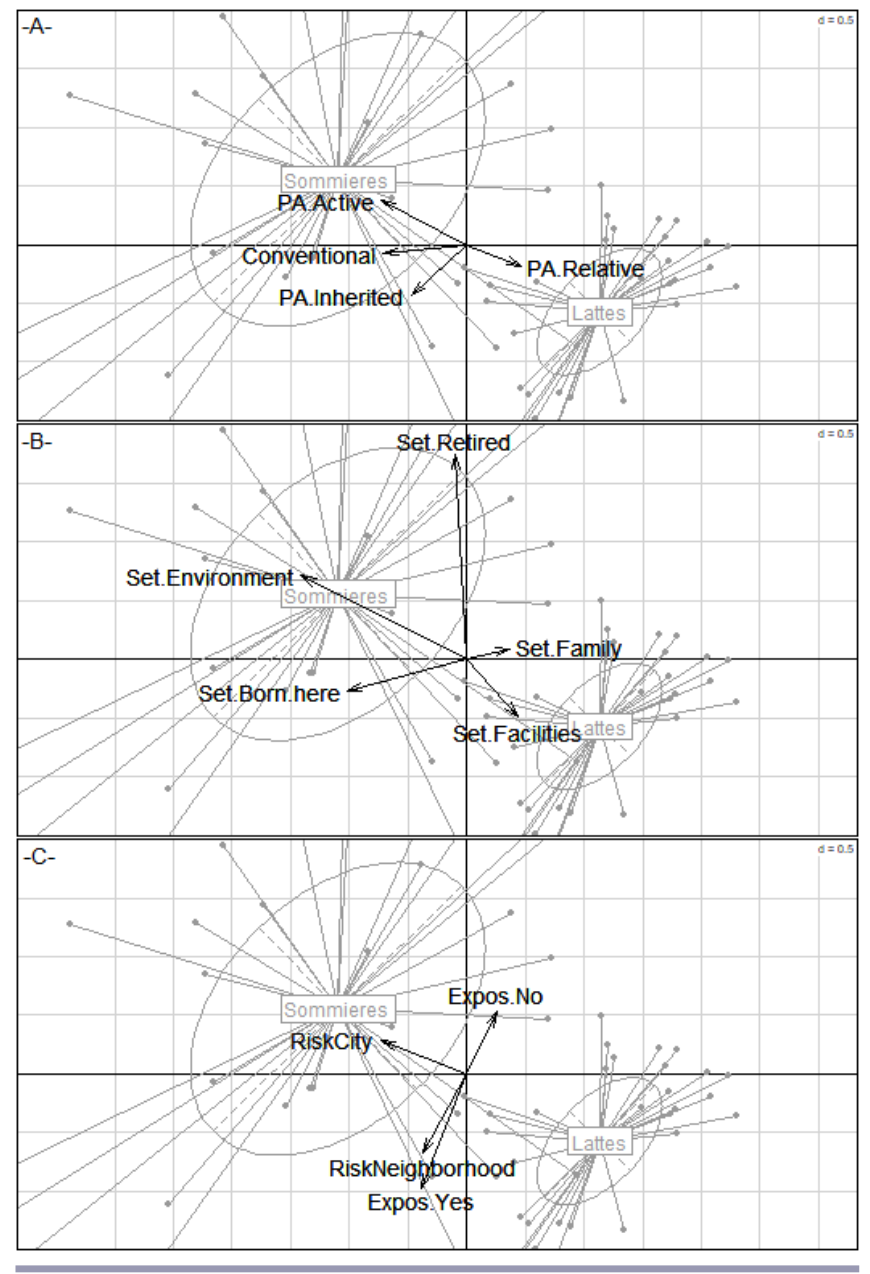

Place attachment shapes risk perception

As illustrated in Figure 3C, risk perception at the town scale is higher in Sommières compared to Lattes $(t=10.952, p<0.001)$. However about half of the respondents in Lattes mentioned that they neither agreed nor disagreed that their town was at risk reflecting a high level of uncertainty. Risk perception at town scale was not correlated to exposure nor the time of residence but we found a positive effect of Active PA $(t=2.97, p=0.003)$. Interestingly, Relative PA, and settling for facilities or family were negatively correlated to risk perception at the town scale. We did not find any difference between risk perceptions at the neighborhood scale between the two towns but it was significantly positively correlated with time of residence $(t=2.790, p=0.006)$ and exposure $(\mathrm{t}=6.743, \mathrm{p}<0.001)$. At this smaller spatial scale, $20 \%$ of our respondents felt their neighborhood was at risk of flooding whereas $60 \%$ thought they were not, and others $(20 \%)$ were unsure but the reason for settling did not explain this pattern.

\section{Adaptations modify place attachment}

In Sommières the Vidourle River is central to the life of the town, being a focal point for leisure and social life. When asked for the meaning of the river the residents in Sommières cite a diversity of meanings from the very positive through to significant danger, to the extent that the river there is personalized and named Vidourle, like a person, and has its own character, i.e., "he is angry," "he is lunatic". On the contrary, as explained above, dykes protect Lattes from the Lez river floods to the extent that the river is not visible from the streets and grounds of the city. Durand (2014) conducted a comparison between the discourses on the Lez River, before and after the adaptations to flood risk. She shows that the perceptions of the river has shifted from heritage to service and the relationship with floods has shifted in focus from emotional to technical considerations. Our hypothesis is that infrastructures built to adapt to floods and the associated technical discourse of protection have contributed to the modification of the attachment to the river and to the place.

This pilot study conducted at two different sites illustrates the potential of the framework presented in Figure 1 to capture the dynamic relationships between mobility, place attachment, risk, and adaptations using a variety of methods (see Fig. 4). Because of the small sample size of the pilot survey, we are limited in the scalability of conclusions but find interesting relationships that suggest further scope for research.

\section{DISCUSSION}

From our literature review and indicative empirical findings we have developed a conceptual model (Fig. 1) to explore the dynamic interactions between place, mobility, perceptions of risk, and adaptation. In doing so we bring a focus to the connections, interactions, and potential feedback between these processes. In our study we find that over time mobility processes can lead to changes in how communities relate to places and that this has implications for risk perception and adaptation choices.

Our results confirm Lewicka's (2011b) suggestion that methodologically disaggregating place types lends greater explanatory power to research that connects sense of place, perception, and related behavior. Results from a conventional place attachment scale suggests that Lattes and Sommières have relatively similar levels of positive overall attachments to their towns. However Figure 3 illustrates that the configurations of attachments varied quite significantly between the populations sampled in the two towns. These differences went on to have explanatory power for our findings on risk perception. As sense of place researchers continue to devise methods that capture variability in attachment, we will be more fully able to capture the characteristics of studied populations and the implications of different types of attachment.

Turning to our conceptual model we consider the impact that mobility has in generating a diversity of place attachments. The socio-demographic structure of each town is the consequence of the variety of origins and of residential routes into and within the towns. The observations in the two towns are consistent with observations by Hummon (1992) who suggests that the experience of mobility influences relationships with place within 
Fig. 4. The relationship between type of place attachment, mobility, and risk. Summary of results from the two towns generated from surveys and interviews

\begin{tabular}{|c|c|c|c|c|c|c|}
\hline \multirow[t]{2}{*}{ Town } & \multicolumn{5}{|c|}{ Survey Results } & \multirow[t]{2}{*}{ Interviews/ secondary literature } \\
\hline & $\begin{array}{l}\text { Place } \\
\text { meaning }\end{array}$ & $\begin{array}{l}\text { Conventional } \\
\text { place } \\
\text { attachment }\end{array}$ & $\begin{array}{l}\text { Place } \\
\text { attachment } \\
\text { types }\end{array}$ & $\begin{array}{l}\text { Sense of } \\
\text { place and } \\
\text { risk } \\
\text { perception }\end{array}$ & $\begin{array}{l}\text { Sense of place } \\
\text { and mobility }\end{array}$ & \\
\hline Sommières & $\begin{array}{l}\text { Quality of } \\
\text { life, } \\
\text { heritage, } \\
\text { river, flood }\end{array}$ & Positive & $\begin{array}{l}\text { Diversity } \\
\text { of types } \\
\text { Dominant } \\
\text { type: } \\
\text { Active }\end{array}$ & \multirow{2}{*}{$\begin{array}{l}\text { Relative } \\
\text { PA and } \\
\text { settling } \\
\text { for } \\
\text { facilities } \\
\text { negatively } \\
\text { correlated } \\
\text { to risk } \\
\text { perception }\end{array}$} & $\begin{array}{l}\text { Born here and } \\
\text { environment } \rightarrow \\
\text { higher } \\
\text { Conventional } \\
\text { PA and Active } \\
\text { PA }\end{array}$ & $\begin{array}{l}\text {-Living with the risk, } \\
\text {-Relying on warning systems and solidarity } \\
\text { for recovery } \\
\text {-Attracts a diversity of socioeconomic } \\
\text { groups } \\
\text {-Strong emotional attachment to the river }\end{array}$ \\
\hline Lattes & $\begin{array}{l}\text { Quality of } \\
\text { life, youth, } \\
\text { wealth, } \\
\text { proximity } \\
\text { to } \\
\text { Montpellier }\end{array}$ & Positive & $\begin{array}{l}\text { Dominant } \\
\text { type: } \\
\text { Relative }\end{array}$ & & $\begin{array}{l}\text { Settling for } \\
\text { facilities } \rightarrow \\
\text { negatively } \\
\text { related to } \\
\text { Active PA }\end{array}$ & $\begin{array}{l}\text {-Protection from risk, construction of } \\
\text { infrastructure for protection } \\
\text {-Attracts wealthy people } \\
\text {-Attachment to the river shifted from } \\
\text { heritage to service from emotional to } \\
\text { technical }\end{array}$ \\
\hline
\end{tabular}

communities. The reasons that people move to a town are indicative of the symbolic meaning that their attachment rests on. For example, there are higher numbers of people with relative types of attachment in Lattes where the most common reason for moving is for professional interests. In turn, the way that people relate to their town shapes what types of physical changes and risks that they are sensitive to in their local area. We found that people that held relative types of attachment, i.e., they did not relate strongly to a place, were also less likely to perceive flood risk. In terms of risk, we found that having a relative attachment for your town was negatively correlated with perceiving flood risk in your town. Our data correlates with Billig's (2006) findings that people's motivation for settling in a place can be linked to subsequent perceptions of risk.

In our conceptual model we suggest that adaptation action, in this instance public infrastructure for flood risk management, can in turn affect mobility choices and place attachments and meanings. Masterson et al. (2017) describe sense of place as a social and ecological linkage, and here we highlight specific mechanisms through which environmental and social change are connected through sense of place. Previous research has demonstrated that changes in land use and character of urban areas (Von Wirth et al. 2016) causes changes in attachment to place. Data from our surveys and interviews allows for a comparison of Lattes and Sommières, and highlights how largescale flood adaptation management and infrastructure can interplay with place attachment and meaning. The two towns were physically and culturally similar 50 years ago and both were subject to severe autumn floods. Risk perception shapes preferences for adaptation policy (Leisorowitz 2006), and although residents and planners in Sommières have cultivated a "living with the flood" strategy favoring individual and collective adaptations such as warning systems, planners for Lattes opted for a "command and control" strategy that led to the construction of big and expensive dykes with the intention to eliminate the risk of flooding. Accordingly in Sommières our survey indicates that people still have an inherited place attachment and a relationship with the natural cycle of the river with a collective memory of floods. In Lattes the relationship with the river has been physically broken (the river is hidden by the dykes) and we observed that sense of place is now much more related to the services that the town can provide rather than the ecological and historical footprint. In this way, adaptations, shaped by residents and policy preferences, can shape place meanings, which in turn attract different types of new residents.

Our review and pilot findings align with Masterson et al.'s (2017) suggestion that sense of place offers a useful approach to understanding perceptions of social and ecological change, and indeed a dynamic approach to place is particularly useful in understanding potential interactions. Identifying systemic trends in groupings of place attachments and meanings can help to explain at a system scale divergences and convergences in interpretations of change (Stedman 2016). Because adaptation is an attempt to keep risk to valued places and objects at an acceptable level (Dow et al. 2013), understanding what it is about a place that is meaningful for individuals makes it easier to understand when changes to a place seem risky to people with certain place meanings and not to others. Indeed, for this reason, sense of place research can help to identify social limits to adaptation (Adger et al. 2009). For policy makers tasked with communicating risk, place research can provide a particularly fruitful lens in addressing the emotional underpinnings of adaptation behavior.

Finally, in the literature discussed above, continuity of place is often identified as significant in a sense of security (Brown et al. 
2003, Morgan 2010), however our findings highlight that place meanings and attachments are far from stable. Future research should consider what types of place attachments and place meanings are most important for establishing a sense of safety because it is a change to these that is most likely to be experienced as a risk. It would be interesting to investigate how place attachment and meaning contributes to safety for different groups, and whether there are significant differences, for example, between long-term residents and relative newcomers, in how safe they feel and what this means for how they manage risk.

\section{CONCLUSION}

In foregrounding the socio-psychological role of place in interpreting place change we gain a new understanding of how individuals and communities manage risk. Our conceptual model and indicative findings focus on the dynamic interactions of sense of place with other social and environmental processes. We suggest that by considering sense of place within a wider system of processes we gain a greater understanding of how settlements and communities engage with environmental change, and are also subsequently shaped by it. As the body of research on the interactions and interdependencies between social and environmental systems grows, a sense of place lens offers useful theoretical and practical insight as to how people experience and manage changing landscapes.

Responses to this article can be read online at: http://www.ecologyandsociety.org/issues/responses. php/10004

\begin{abstract}
Acknowledgments:
This paper was developed as part of the Belmont Forum funded "Multi-scale adaptations to global change and their impacts on vulnerability in coastal areas" (MAGIC) project. The project was supported by the UK Natural Environment Research Council (NE/ L008807/1). We would like to thank Kate Brown and Tom Chaigneau for their reading of earlier drafts and the comments from two reviewers.
\end{abstract}

\section{LITERATURE CITED}

Adamo, S. B. 2010. Environmental migration and cities in the context of global environmental change. Current Opinion in Environmental Sustainability 2(3):161-165. http://dx.doi.org/10.1016/ j.cosust.2010.06.005

Adams, H. 2016. Why populations persist: mobility, place attachment and climate change. Population and Environment 37 (4):429-448. http://dx.doi.org/10.1007/s11111-015-0246-3

ADEME (L'Agence de l'environnement et de la maîtrise de l'énergie) and Meteo-France. 2011. Changement climatique au 20eme siècle en Langduedoc Roussillon. Données et références, Montpellier. Meteo-France, Paris, France.

Adger, W. N., J. Barnett, F. S. Chapin III, and H. Ellemor. 2011. This must be the place: underrepresentation of identity and meaning in climate change decision-making. Global Environmental Politics 11(2):1-25. http://dx.doi.org/10.1162/GLEP_a 00051
Adger, W. N., S. Dessai, M. Goulden, M. Hulme, I. Lorenzoni, D. R. Nelson, L. O. Naess, J. Wolf, and A. Wreford. 2009. Are there social limits to adaptation to climate change? Climatic Change 93(3-4):335-354. http://dx.doi.org/10.1007/s10584-008-9520$\underline{Z}$

Agyeman, J., P. Devine-Wright, and J. Prange. 2009. Close to the edge, down by the river? Joining up managed retreat and place attachment in a climate changed world. Environment and Planning A 41(3):509-513. http://dx.doi.org/10.1068/a41301

Anton, C. E., and C. Lawrence. 2014. Home is where the heart is: the effect of place of residence on place attachment and community participation. Journal of Environmental Psychology 40:451-461. http://dx.doi.org/10.1016/j.jenvp.2014.10.007

Bailey, E., P. Devine-Wright, and S. Batel. 2016. Using a narrative approach to understand place attachments and responses to power line proposals: the importance of life-place trajectories. Journal of Environmental Psychology 48:200-211. http://dx.doi. org/10.1016/j.jenvp.2016.10.006

Bernardo, F. 2013. Impact of place attachment on risk perception: exploring the multidimensionality of risk and its magnitude. Estudios de Psicología 34(3):323-329. http://dx.doi. org/10.1174/021093913808349253

Billig, M. 2006. Is my home my castle? Place attachment, risk perception, and religious faith. Environment and Behavior 38 (2):248-265. http://dx.doi.org/10.1177/0013916505277608

Bonaiuto, M., S. Alves, S. De Dominicis, and I. Petruccelli. 2016. Place attachment and natural hazard risk: research review and agenda. Journal of Environmental Psychology 48:33-53. http://dx. doi.org/10.1016/j.jenvp.2016.07.007

Bonaiuto, M., G. M. Breakwell, and C. Ignacio. 1996. Identity processes and environmental threat: the effects of nationalism and local identity upon perception of beach pollution. Journal of Community \& Applied Social Psychology 6(3):157-175. http://dx. doi.org/10.1002/(SICI)1099-1298(199608)6:3<157::AID-CASP367>3.0. CO:2-W

Bowlby, J. 1969. Attachment and loss. Basic Books, New York, New York, USA.

Brehm, J. M., B. W. Eisenhauer, and R. C. Stedman. 2013. Environmental concern: examining the role of place meaning and place attachment. Society \& Natural Resources 26(5):522-538. http://dx.doi.org/10.1080/08941920.2012.715726

Brown, B., D. D. Perkins, and G. Brown. 2003. Place attachment in a revitalizing neighborhood: individual and block levels of analysis. Journal of Environmental Psychology 23(3):259-271. http://dx.doi.org/10.1016/S0272-4944(02)00117-2

Burley, D., P. Jenkins, S. Laska, and T. Davis. 2007. Place attachment and environmental change in coastal Louisiana. Organization \& Environment 20(3):347-366. http://dx.doi. org/10.1177/1086026607305739

Chapin III, F. S., and C. N. Knapp. 2015. Sense of place: a process for identifying and negotiating potentially contested visions of sustainability. Environmental Science \& Policy 53:38-46. http://dx. doi.org/10.1016/i.envsci.2015.04.012 
Cheng, C. K., and S. F. Chou. 2015. The influence of place change on place bonding: a longitudinal panel study of renovated park users. Leisure Sciences 37(5):391-414. http://dx.doi. org/10.1080/01490400.2015.1021883

Clarke, D., C. Murphy, and I. Lorenzoni. 2018. Place attachment, disruption and transformative adaptation. Journal of Environmental Psychology 55:81-89. http://dx.doi.org/10.1016/j. jenvp.2017.12.006

De Dominicis, S., F. Fornara, U. G. Cancellieri, C. Twigger-Ross, and M. Bonaiuto. 2015. We are at risk, and so what? Place attachment, environmental risk perceptions and preventive coping behaviours. Journal of Environmental Psychology 43:66-78. http://dx.doi.org/10.1016/j.jenvp.2015.05.010

De Sherbinin, A., M. Castro, F. Gemenne, M. M. Cernea, S. Adamo, P. M. Fearnside, G. Krieger, S. Lahmani, A. OliverSmith, A. Pankhurst, et al. 2011. Preparing for resettlement associated with climate change. Science 334(6055):456-457. http:// dx.doi.org/10.1126/science.1208821

De Sherbinin, A., M. Levy, S. Adamo, K. MacManus, G. Yetman, V. Mara, L. Razafindrazay, B. Goodrich, T. Srebotnjak, C. Aichele, and I. Pistolesi. 2012. Migration and risk: net migration in marginal ecosystems and hazardous areas. Environmental Research Letters 7(4):045602. http://dx.doi.org/10.1088/1748-9326/7/4/045602

Devine-Wright, P. 2013. Explaining "NIMBY" objections to a power line: the role of personal, place attachment and projectrelated factors. Environment and Behavior 45(6):761-781. http:// dx.doi.org/10.1177/0013916512440435

Devine-Wright, P. 2014. Dynamics of place attachment in a climate changed world. Chapter 13 in L. C. Manzo, and P. DevineWright, editors. Place attachment: advances in theory, methods and applications. Routledge, London, UK.

Devine-Wright, P., and Y. Howes. 2010. Disruption to place attachment and the protection of restorative environments: a wind energy case study. Journal of Environmental Psychology 30 (3):271-280. http://dx.doi.org/10.1016/j.jenvp.2010.01.008

Dow, K., F. Berkhout, B. L. Preston, R. J. T. Klein, G. Midgley, and M. R. Shaw. 2013. Limits to adaptation. Nature Climate Change 3(4):305-307. http://dx.doi.org/10.1038/nclimate1847

Dray S., and A. B. Dufour. 2007. The ade4 package: implementing the duality diagram for ecologists. Journal of Statistical software (22):1-20.

Durand, S. 2014. Vivre avec la possibilité d'une inondation? Ethnographie de l'habiter en milieu exposé et prisé. Sciences de l'Homme et Société, Aix-Marseille Université, France.

Easthope, H. 2009. Fixed identities in a mobile world? The relationship between mobility, place, and identity. Identities: Global studies in Culture and Power 16(1):61-82. http://dx.doi. org/10.1080/10702890802605810

Ellis, N. R., and G. A. Albrecht. 2017. Climate change threats to family farmers' sense of place and mental wellbeing: a case study from the Western Australian Wheatbelt. Social Science \& Medicine 175:161-168. http://dx.doi.org/10.1016/j.socscimed.2017.01.009
Finucane, M. L., A. Alhakami, P. Slovic, and S. M. Johnson. 2000. The affect heuristic in judgments of risks and benefits. Journal of Behavioral Decision Making 13(1):1-17. http://dx.doi.org/10.1002/(SICI) 1099-0771(200001/03)13:1<1::AID-BDM333>3.0.CO;2-S

Fried, M. 2000. Continuities and discontinuities of place. Journal of Environmental Psychology 20(3):193-205. http://dx.doi. org/10.1006/jevp.1999.0154

Fullilove, M. T. 1996. Psychiatric implications of displacement: contributions from the psychology of place. American Journal of Psychiatry 153(12):1516-1523. http://dx.doi.org/10.1176/ajp.153.12.1516

Grothmann, T., and A. Patt. 2005. Adaptive capacity and human cognition: the process of individual adaptation to climate change. Global Environmental Change 15(3):199-213. http://dx.doi. org/10.1016/j.gloenvcha.2005.01.002

Gustafson, P. 2001. Meanings of place: everyday experience and theoretical conceptualizations. Journal of Environmental Psychology 21(1):5-16. http://dx.doi.org/10.1006/jevp.2000.0185

Gustafson, P. 2014. Place attachment in an age of mobility. Chapter 3 in L. C. Manzo and P. Devine-Wright, editors. Place attachment: advances in theory, methods and applications. Routledge, London, UK.

Harries, T. 2008. Feeling secure or being secure? Why it can seem better not to protect yourself against a natural hazard. Health, Risk \& Society 10(5):479-490. http://dx.doi.org/10.1080/13698570802381162

Hawkins, R. L., and K. Maurer. 2011. 'You fix my community, you have fixed my life': the disruption and rebuilding of ontological security in New Orleans. Disasters 35(1):143-159. http://dx.doi.org/10.1111/j.1467-7717.2010.01197.x

Hernández, B., M. C. Hidalgo, M. E. Salazar-Laplace, and S. Hess. 2007. Place attachment and place identity in natives and non-natives. Journal of Environmental Psychology 27(4):310-319. http://dx.doi.org/10.1016/j.jenvp.2007.06.003

Hidalgo, M. C., and B. Hernandez. 2001. Place attachment: conceptual and empirical questions. Journal of Environmental Psychology 21(3):273-281. http://dx.doi.org/10.1006/jevp.2001.0221

Hummon, D. M. 1992. Community attachment: local sentiment and sense of place. Pages 253-278 in I. Altman and S. M. Low, editors. Place attachment. Plenum, New York, New York, USA. http://dx.doi.org/10.1007/978-1-4684-8753-4 12

INSEE (L'Institut national de la statistique et des études économiques). 2015. Statistics. INSEE, Paris, France. [online] URL: https://www.insee.fr/en/statistiques

Jacobs, M. H., and A. E. Buijs. 2011. Understanding stakeholders' attitudes toward water management interventions: role of place meanings. Water Resources Research 47(1). http://dx.doi. org/10.1029/2009WR008366

Jacquet, J. B., and R. C. Stedman. 2013. Perceived impacts from wind farm and natural gas development in northern Pennsylvania. Rural Sociology 78(4):450-472. http://dx.doi. org/10.1111/ruso.12022

Jaeger, C. C., T. Webler, E. A. Rosa, and O. Renn. 2013. Risk, uncertainty and rational action. Routledge, London, UK. 
Knez, I. 2005. Attachment and identity as related to a place and its perceived climate. Journal of Environmental Psychology 25 (2):207-218. http://dx.doi.org/10.1016/j.jenvp.2005.03.003

Korpela, K. M. 1989. Place-identity as a product of environmental self-regulation. Journal of Environmental Psychology 9(3):241-256. http://dx.doi.org/10.1016/S0272-4944 (89)80038-6

Lewicka, M. 2005. Ways to make people active: the role of place attachment, cultural capital, and neighborhood ties. Journal of Environmental Psychology 25(4):381-395. http://dx.doi.org/10.1016/ j.jenvp.2005.10.004

Lewicka, M. 2011a. Place attachment: how far have we come in the last 40 years? Journal of Environmental Psychology 31 (3):207-230. http://dx.doi.org/10.1016/j.jenvp.2010.10.001

Lewicka, M. 2011b. On the varieties of people's relationships with places: Hummon's typology revisited. Environment and Behavior 43(5):676-709. http://dx.doi.org/10.1177/0013916510364917

Lewicka, M. 2013. Localism and activity as two dimensions of people-place bonding: the role of cultural capital. Journal of Environmental Psychology 36:43-53. http://dx.doi.org/10.1016/j. jenvp.2013.07.002

Leiserowitz, A. 2006. Climate change risk perception and policy preferences: the role of affect, imagery, and values. Climatic Change 77(1-2):45-72. http://dx.doi.org/10.1007/s10584-006-9059-9

Maldonado, J. K., C. Shearer, R. Bronen, K. Peterson, and H. Lazrus. 2013. The impact of climate change on tribal communities in the US: displacement, relocation, and human rights. Climatic Change 120(3):601-614. http://dx.doi.org/10.1007/s10584-013-0746$\underline{z}$

Martínez, M. L., A. Intralawan, G. Vázquez, O. Pérez-Maqueo, P. Sutton, and R. Landgrave. 2007. The coasts of our world: ecological, economic and social importance. Ecological Economics 63(2-3):254-272. http://dx.doi.org/10.1016/j. ecolecon.2006.10.022

Masterson, V. A., R. C. Stedman, J. Enqvist, M. Tengö, M. Giusti, D. Wahl, and U. Svedin. 2017. The contribution of sense of place to social-ecological systems research: a review and research agenda. Ecology and Society 22(1):49. http://dx.doi.org/10.5751/ ES-08872-220149

Masuda, J. R., and T. Garvin. 2006. Place, culture, and the social amplification of risk. Risk Analysis 26(2):437-454. http://dx.doi. org/10.1111/j.1539-6924.2006.00749.X

McCaughey, J. W., P. Daly, I. Mundir, S. Mahdi, and A. Patt, A. 2018. Socio-economic consequences of post-disaster reconstruction in hazard-exposed areas. Nature Sustainability 1:38-43. http://dx. doi.org/10.1038/s41893-017-0002-Z

McGranahan, G., D. Balk, and B. Anderson. 2007. The rising tide: assessing the risks of climate change and human settlements in low elevation coastal zones. Environment and Urbanization 19 (1):17-37. http://dx.doi.org/10.1177/0956247807076960

McLeman, R. A. 2011. Settlement abandonment in the context of global environmental change. Global Environmental Change 21:S108-S120. http://dx.doi.org/10.1016/j.gloenvcha.2011.08.004
Morgan, P. 2010. Towards a developmental theory of place attachment. Journal of Environmental Psychology 30(1):11-22. http://dx.doi.org/10.1016/j.jenvp.2009.07.001

Neumann, B., A. T. Vafeidis, J. Zimmermann, R. J. Nicholls. 2015. Future coastal population growth and exposure to sea-level rise and coastal flooding-a global assessment. PLOS ONE 10 (3):0118571. http://dx.doi.org/10.1371/journal.pone.0118571

Rey-Valette, H., B. Rulleau, A. P. Hellequin, C. Meur-Férec, and H. Flanquart. 2015. Second-home owners and sea-level rise: the case of the Languedoc-Roussillon region (France). Journal of Policy Research in Tourism, Leisure and Events 7(1):32-47. http:// dx.doi.org/10.1080/19407963.2014.942734

Savage, M. 2010. The politics of elective belonging. Housing, Theory and Society 27:115-161. http://dx.doi.org/10.1080/14036$\underline{090903434975}$

Stedman, R. C. 2003. Is it really just a social construction?: The contribution of the physical environment to sense of place. Society \& Natural Resources 16(8):671-685. http://dx.doi. org/10.1080/08941920309189

Stedman, R. C. 2006. Understanding place attachment among second home owners. American Behavioral Scientist 50 (2):187-205. http://dx.doi.org/10.1177/0002764206290633

Stedman, R. C. 2016. Subjectivity and social-ecological systems: a rigidity trap (and sense of place as a way out). Sustainability Science 11(6):891-901. http://dx.doi.org/10.1007/s11625-016-0388y

Surjan, A., G. A. Parvin, and Atta-ur-Rahman, and R. Shaw. 2016. Expanding coastal cities: an increasing risk. Urban Disasters and Resilience in Asia 79-90. http://dx.doi.org/10.1016/ B978-0-12-802169-9.00006-9

Tacoli, C. 2009. Crisis or adaptation? Migration and climate change in a context of high mobility. Environment and Urbanization 21(2):513-525. http://dx.doi.org/10.1177/0956247809342182

Venables, W. N., and B. D. Ripley. 2002. Modern applied statistics with S. Springer, New York, New York, USA. http://dx.doi. org/10.1007/978-0-387-21706-2

Von Wirth, T., A. Grêt-Regamey, C. Moser, and M. Stauffacher. 2016. Exploring the influence of perceived urban change on residents' place attachment. Journal of Environmental Psychology 46:67-82. http://dx.doi.org/10.1016/j.jenvp.2016.03.001

Wachinger, G., O. Renn, C. Begg, and C. Kuhlicke. 2013. The risk perception paradox-implications for governance and communication of natural hazards. Risk Analysis 33(6):1049-1065. http://dx.doi. org/10.1111/j.1539-6924.2012.01942.X

Watts, N., W. N. Adger, P. Agnolucci, J. Blackstock, P. Byass, W. Cai, S. Chaytor, T. Colbourn, M. Collins, A. Cooper, et al. 2015. Health and climate change: policy responses to protect public health. Lancet 386(10006):1861-1914. http://dx.doi.org/10.1016/ $\underline{\text { S0140-6736(15)60854-6 }}$

Wester-Herber, M. 2004. Underlying concerns in land-use conflicts - the role of place-identity in risk perception. Environmental Science \& Policy 7(2):109-116. http://dx.doi. org/10.1016/j.envsci.2003.12.001 
Willox, A. C, S. L. Harper, J. D. Ford, K . Landman, K. Houle, V. L. Edge, and the Rigolet Inuit Community Government. 2012. "From this place and of this place": climate change, sense of place, and health in Nunatsiavut, Canada. Social Science \& Medicine 75(3):538-547. http://dx.doi.org/10.1016/j.socscimed.2012.03.043 
Appendix 1. Flood map of Lattes.

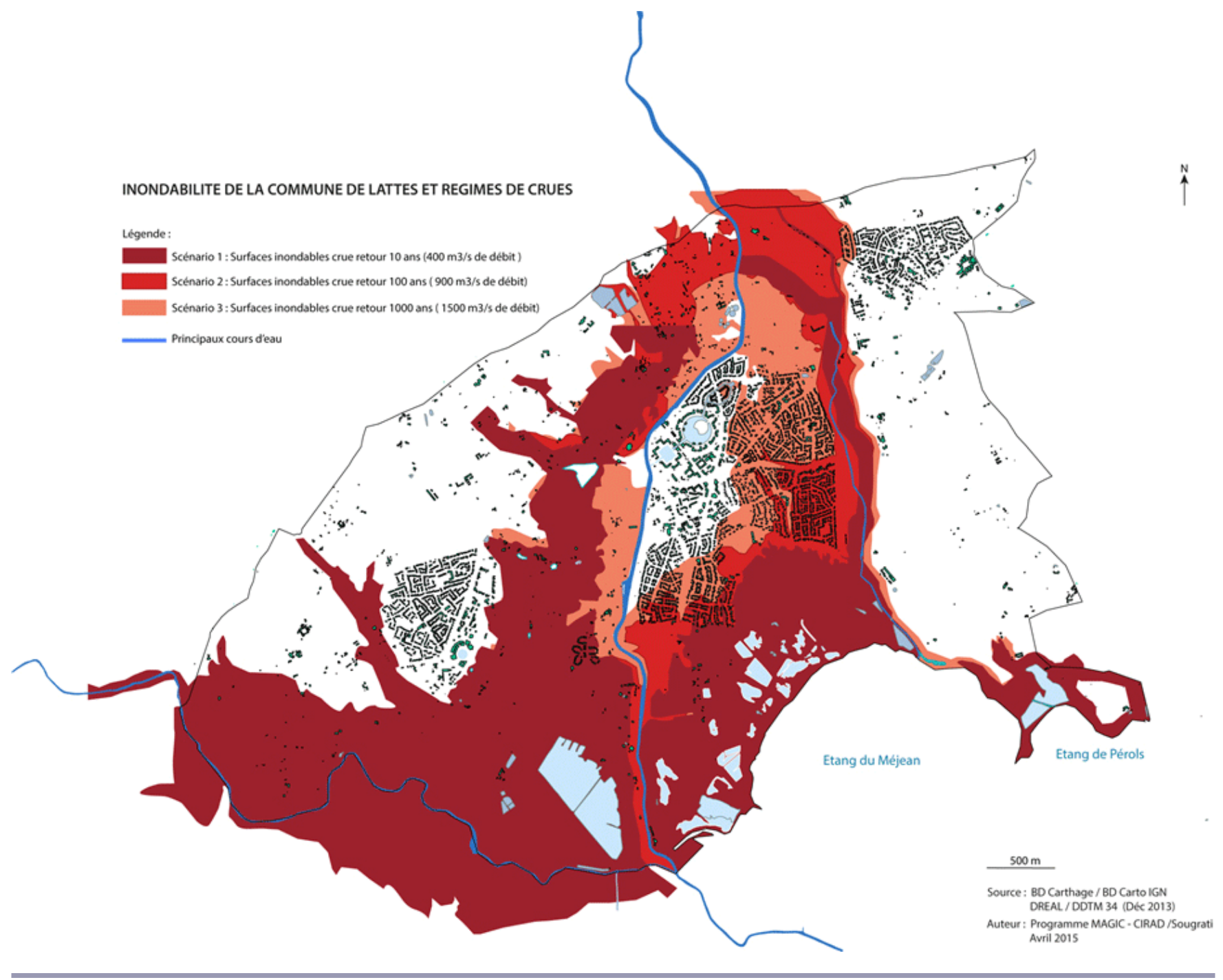


Appendix 2. Flood map of Sommières.

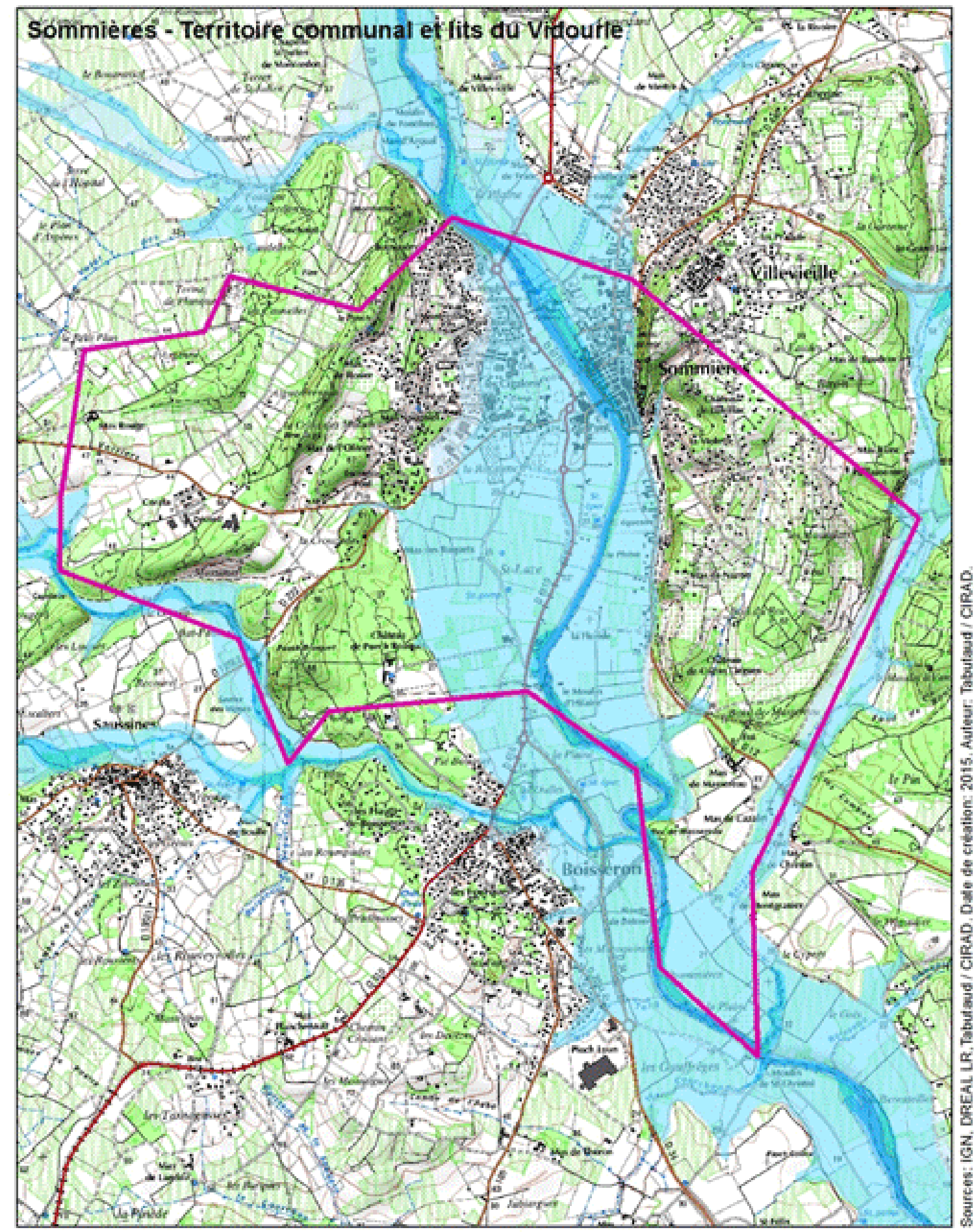

Lits du Vidourle

Lit
Lit mineur
Lit moyen

\begin{abstract}
Lit majeur
\end{abstract}
Lit majeur exceptionnel
Territoire de Sommières

Périmetre communal
$\stackrel{N}{N}$ 